tion comes out. Vomiting may be the only marked sign of disorder. Over-eating, improper food, gastric catarrh, the advent of scarlatina or of meningitis, may be the thing signified by it. Though time is so important, our diagnosis has to wait, and on it must wait our therapeutics, for a random stroke among infants is full of peril.

Still more remarkable is the fact that diseases well defined in adults show a less marked structural change in children, and entail death when ordinarily this termination would not be feared. Hence the practitioner who fails to note the principle just named, the higher impressionability of the organism in early years, will see children die unexpeetedly, when the physical changes of the organ are far less in extent and development than would appear likely to endanger life. Even typhoid fever presents important differences as compared with the same disease in adults. The characteristic lesions of the intestinal glands, submucous tissue, and spleen, are very moderately developed among children. Ample evidence of this is to be found in the classical works of Barthez and Rilliet, and Alfred Vogel, whose observations I have often con. firmed. The practical deduction to be made is, that we must not estimate the gravity of the case from the absence or presence of severe diarrhœa, hæmorrhage, or perforation. We must also infer from this order of facts, that the child's strength may need all we can do to sustain it, from the general sympathy of the body with the special processes going on in organs, while the evidences of those processes may be little developed.

Typhoid fever supplies us with a striking illustration of the object of this paper. There is scarcely a drug, mineral or vegetable, which has not been advised as curative of this malady. From quinine to mercury, remedy after remedy has been declared able to control its course. What are the facts? Under the most varied treatment, only from 5 to Io per cent. die, the mild and severe cases being collected together; and I believe that under a judicious expectation these results may be improved, As to drugs, the last English writer on children's diseases, Dr. Hillier, speaks in a manner so decisive, that I must give the passage. "In the vast majority of cases of typhoid fever in children, drugs are scarcely needed. The points to be attended to are : to keep the patient in bed in a well ventilated room, to attend scrupulously to the removal of all discharges, to bathing the skin once or twice daily with tepid water, and to a frequent changing of the bed and body linen. Diet is also of supreme importance; it must be light, fluid or pultaceous, and nutritious. Milk and beef-tea should form the chief articles of nourishment; they may be combined with arrow-root, semolina, vermicelli, or ground rice. Eggs may also be given, beaten up in milk, or combined with wine or brandy. If there is great thirst, cold water, in small quantities at a time, or cold tea may be given. No solid food should be given until the end of from twenty-one to twenty-eight days, and must be forbidden for a longer period if diarrhœa continue. I have already spoken on the use of stimulants. They are indicated, in the majority of cases, from the end of the tenth or twelfth day." The author goes on to treat of the measures needful to restrain excessive diarrhœa, etc.; but the above quotation gives a complete view of the general treatment of the disorder, and offers an excellent model of the numerous attentions demanded of the physician apart from the employment of medicines.

I have occupied myself at such length with the exposition of principles, that I have left no space for their detailed application. Notwith. standing, I must refer to one branch of therapeutics, having an essential relation to the peculiarities of children. I allude to the use of alcohol. It has been already remarked that the modern practice of medicine takes more heed of the patient than of the diagnosis. If, as I believe, excesses have been committed in England in this aspect, the balance on the whole inclines to the side of profit. The description just given of the specialities of the child's physiology and pathology, has been to little purpose if it have not become apparent that the careful stimulation of children is even of more moment than among adults. A practitioner should always deliberately ask himself this question at the bedside of a child-Is his strength giving way? In infancy, it is indispensable that a well-adapted food should be frequently given; the temperature becomes lowered with great rapidity under certain unfavourable conditions; while long-continued pain and large and numerous discharges soon exhaust the power of resistance. We have, in alcohol, a precious resource, in aid of food, enabling us often to preserve the child even under the most unpromising circumstances. Here British medicine has achieved a real advance, of which abnndant proof can be found in the essay, published last year by Dr. Gingeot of Paris, "On the Therapeutical Employment of Alcohol among Children." It is confessedly based on work done in this country, and contains valuable evidence of the utility of this agent in many severe diseases. I am convinced that it is not yet used among children as systematically as is desirable. I would, however, add the caution, that excessive stimulation is to be sedulously avoided in childhood. The amount of brandy ordered by some physicians in children's diseases fills me with astonishment, for its perturbative effects in large doses are most grave at an early age. All the good it is capable of rendering is obtainable from an ounce to an ounce and a half in twenty-four hours. Much less than this is all that is required in very young subjects.

I wished to add something on the use of mercury, opium, antimony, purgatives and blisters, in reference to children; though, in truth, I find it easier, as the Roman said of Carthage, to be silent than to speak little of them. I shall content myself with stating that he who least often and least freely avails himself of these and similar means of med. ication, will be the most successful in practice; and that he who pays most attention to prevention and hygiene in their comprehensive sense, will save the largest number of lives. In this latter aspect, our field of labour is hourly expanding; and every member of the profession must feel it to be a noble task to work a portion of that field.

I will conclude by declaring that in infantile pathology there are two salient points to be kept in mind; and Dr. Jaccoud has so well stated them in reference to one disease, that I shall quote his words. "In short, do not forget that there exist pneumonics, and not pneumonias; and you must not confound rational therapeutical reserve with the inertia of a foregone conclusion."

\section{LETTSOMIAN LECTURES}

\section{THE MEDICAL SOCIETY OF LONDON IN 1869.}

By WILLIAM ADAMS, F.R.C.S.,

Surgeon to the Royal Orthopædic and Great Northern Hospitals, etc.

\section{LECTURE I}

\section{Acute Rheumatic Affections of the Foints; their Pathology and} Treatment.

AFTER referring to the great advance made in the modern treatment of joint diseases, a result obtained by our more exact knowledge of structural anatomy, and the physiology of nutrition, as well as the study of inflammation in its physiological and pathological bearings, Mr. Adams proceeded to consider whether the classification and description of jointdiseases should be made upon an anatomical or on a pathological basis. He preferred the pathological arrangement, considering that the anatomical basis might lead to a much too narrow view of the pathology of diseases of the joints, in reference to the constitutional conditions upon which they depend.

As some authors consider the synovial membrane, and the cancellous tissue of the bone, to be the only structures liable to primary inflamma. tion, Mr. Adams produced some evidence to show that both the ligaments and articular cartilages were frequently the primary seat of disease; the ligaments suffering from inflammation after sprains and injuries which, when occurring in strumous constitutions, frequently led to complete destruction of the joint, as seen in hip-joint disease; which, $M r$. Adams believes, generally commences in the round ligament.

The articular cartilages are liable to changes of nutrition, scarcely separable from the effects of inflammation in its more chronic form, such as fibrous degeneration; and also hypertrophy, and subsequent ossification, which Mr. Adams first pointed out as occurring in the production of osteophytes in chronic rheumatic arthritis. They are also believed to be the seat of true inflammatory changes, as represented by the textural changes of cell-nutrition; and Professor $\mathrm{C}$. O. Weber considers that suppuration may occur in the texture of articular cartilage. Mr. Adams, however, expressed some doubt upon this point, though admitting the other inflammatory changes.

A very large proportion of all the cases of joint-disease met with in practice, are associated either with a rheumatic or with a strumous constitutional condition; and the influence which these constitutional conditions exert on the local affection, Mr. Adams proposed to make the special subject of the present lectures, thus regarding joint-diseases from a constitutional point of view.

The first, and indeed the great question to be considered, is-To what extent is the inflammatory process, when affecting the joints, modified with respect to its results, or so-called terminations in adhesion, suppuration, and ulceration, by the constitutional conditions of rheumatism and struma? Mr. Adams believes the general law of rheumatic and strumous inflammation to be that in the rheumatic form, whether acute, subacute, or chronic, there is no disposition to the destructive processes of suppuration and ulceration; whilst a disposition to those destructive processes constitutes the chief pathological characters of the strumous
inflammation. 
Does suppuration ever occur during the progress of acute rheumatic inflammation in the joints, the eye, the pericardium, or pleura, or in any other structures of the body? Mr. Adams believes that suppuration never does occur as the result of rheumatic inflammation in any organ or tissue of the body, but that rheumatic inflammation always exhibits the same tendency to terminate in the effusion of serum, and plastic lymph, by the organisations of which adhesions are formed.

In the eye, the ophthalmic surgeon has no fear that rheumatic iritis will terminate in suppuration or ulceration; its termination in adhesion is constantly seen, and its prevention is the chief object of treatment. In the pericardium and pleura, when attacked by rheumatic inflammation, the physician looks forward to the same termination. Rheumatic inflammation, therefore, exhibits itself essentially as a productive process, and strumous inflammation as a destructive process.

In the general pathology of rheumatism, it is of importance to ascertain whether there are any modifying influences which may alter the ordinary progress and termination of rheumatic inflammation. The most important modifying influences are those of struma, syphilis, gonorrhœa, and leucorrhoea. Of these it may be said that none of them produce any essential modification as to the results of the rheumatic inflammation. No tendency to suppuration or ulceration is induced by any of these complications, but still each of them exerts some special influence on the progress of the rheumatic inflammation.

Mr. Adams proceeded to the description of Acute Rheumatic Synovitis: its general characters, symptoms, and progress. The doubt expressed by the late Dr. Todd, as to the true inflammatory nature of the jointaffection, was removed, by reference to the post mortern examinations of several patients who had died from cerebral or cardiac complications of rheumatic fever, from the fourth to the twenty-fifth day. In all these examinations, the morbid appearances were essentially of a similar character, viz., inflammation of the synovial membrane, with effusion into the joint of serum, with albuminous shreds, or flocculi of lymph floating in it. In no instance was the existence of pus, or of any ulceration of the articular cartilage described. Mr. Adams regretted that so few post mortem examinations were on record, in which the joints had been examined in patients who had died during an attack of rheumatic fever.

In the treatment, he spoke of the value of the hot-air bath, applied whilst the patient is in bed, and alkaline fomentations to the inflamed joints. The action of alkalies, both externally and internally, he believed was not so much in neutralising the excess of acid in the system, as in their tendency to fluidise the blood, by their direct chemical action upon the fibrine, which is known to be much increased in quantity in this affection; the effect of this in the local application was to remove the condition of stasis of the blood-corpuscles, always existing in in flammation. The action of mercury was also discussed in reference to its power of diminishing the quantity of lymph effused, of preventing its organisation, and promoting its absorption, especial reference being made to the experience of ophthalmic surgeons in the treatment of rheumatic iritis.

The next affection described by Mr. Adams, was Acute Rheumatic Synovitis in an Aggravated Form, Localised in one foint during the early stage of Rheumatic Fever, Gonorrhoal, or Genital Rheumatism. These cases at their commencement exhibit the ordinary symptoms of rheumatic fever; but, instead of metastasis of the articular inflammation occurring, the inflammation in an aggravated form quickly localises itself in one joint, usually the knee or the hip-joint; so that the jointaffection quickly becomes the predominant feature. The acute symptoms generally continue from three to five months. Suppuration is often feared, but no liability to this process exists. It terminates neither in suppuration nor in ulceration, but in the effusion of lymph and organisation of adhesions within and surrounding the joint. A specimen, exhibiting these conditions, was shown to the Society.

The most frequent cause of this affection is the previous existence of gonorrhœa, but sometimes a history of leucorrhœa only can be traced. Hence the propriety of the term genital rheumatism The explanation of these cases, depending upon a mild form of purulent infection, was considered by Mr. Adams as very doubtful, as only one joint is usually affected, and there is no tendency to suppuration; whilst, in pyæmia, several joints are generally involved, and suppuration constantly follows; the pathology is therefore obscure.

The constitutional and local treatment are the same as in the ordinary form of acute rheumatic synovitis, but the intense pain can be best relieved by the subcutaneous injection of morphia. Possibly, the American plan of extension by weights, proved to be so successful in removing the most acute pain of hip-joint disease, and also the pain in some cases of inflammation of the knee-joint, might meet with equal success in this affection, and is worthy of trial.

For the removal of the remaining stiffness of the joint, the use of the steam-bath, shampooing, and passive motion were recommended to be commenced early; and, if these failed, forcible extension under chloroform was to be used, and repeated every two or three weeks, very little being attempted each time, the restoration of motion thus being very slowly and gradually obtained.

\section{ON THE TREATMENT OF CHOLERA.}

\author{
By AQUILLA SMITH, M.D., \\ King's Professor of Materia Medica in Trinity College, and Physician to \\ Sir Patrick Dun's Hospital, Dublin.
}

THE records of Medicine furnish many instances in which writers at an early period, without any knowledge of pathology or of the many other appliances of modern science to the art of medicine, have shown that they were not inferior to practitioners of our own time as close observers of many diseases; and that they occasionally adopted modes of treatment which have been revived in modern times, or unconsciously put forward as original views based on the accumulated experience of modern observers. As an example of a clear and accurate description of ordinary cholera, I quote the following from Aëtius, who, according to Le Clerc, flourished in the fourth century; while Freind asserts, "It is plain, even from his own books, that he did not write till the very end of the fifth or the beginning of the sixth century." (History of Physic, 2nd edit., vol. i, p. 4.)

"Cholera appellatur, quum ob multas cruditates vomitus biliosus et nidorosus et acidus aboritur, ad plures horas continuè perseverans, et venter infernè eadem excernit : sequiturque sitis, et exudatio, et impeditus pulsus, musculorumque manuum ac pedum, maximè verò surarum contractio et tensio. Siquis igitur mox in principio aut coacervatim, ea quæ efferuntur cohibere aggrediatur, is majoris mali auctor erit: inutilia enim quum sint, evacuatione opus habent. Quare convenit, si non sponte ferantur, opportunè irritare, aquâ tepidâ exhibitâ, ac ægro vomere jusso. Aqua enim mulsa mordacitatem operatur, torsionesque auget: aqua verò oleo mixta, auget fluxiones. Quare aquâ tepidâ potatâ vomant, quotiescunque quidem cibis nimiùm fuerint expleti, priusquàm illi corrumpantur. Adjuvare etiam oportet per sedem excretionem; alienum enim velut venenum insidens, et ventrem ac intestina rodit. Per vomitus itaque opportunam provocationem, vomitus ipse solvitur et cessat, et humores ex universo corpore attrahit. - At vero ubi intolerabilis effusio existat, et pulsus emolliatur, apprehendatque frigiditas et exudatio, aliquando etiam singultus, ad vinum transeundum est mediocriter adstringens. - Vini multitudo vitanda est, ac omni arte conandum ut ipsos sopiamus.-Alvo autem adhuc egerente, amylum cum decoctione capitum papaveris per clysterem infundatur: simul enim et cohibet et refrigerrat, et somnum inducit." (Medica Artis Principes, fol., 1567; Aëtius, Tetrabiblos, iii, Sermo i, cap. xii, p. 45o.)

This description of cholera corresponds in the following particulars with the disease with which we have been for some years past too familiar; viz., vomiting and purging, continuing for many hours; thirst and sweating; an embarrassed pulse; cramps, chiefly in the legs; coldness; and at times hiccup.

Epidemics of cholera and fever bear so close a relation to sporadic cases, when one or the other occurs in a severe form, it may be assumed that the principles of treatment which are applicable to the sporadic form of cholera may be resorted to when the disease is epidemic. Sir Thomas Watson, in "A Lecture on Cholera and Diarrhcea", published in the BRITISH MEDICAL JourNaL of July I 8 th, I 868 , admits that he finds " it necessary to modify considerably some advice that he formerly gave as to the treatment of a disorder which appears to be again increasingly prevalent throughout the country," and to a great extent adopts the views of Dr. George Johnson "On the Pathology and Treatment of Cholera", published in the Medico-Chirurgical Transactions, vol. L. Dr. Johnson says: "I will proceed at once to state the main conclusions at which, after a careful study of the disease, I have myself arrived, together with the reasons which have led me to these conclusions. Upon them I invite comment and criticism." (P. IO3.) It is not my purpose to impugn any of the opinions set forth by Dr. Johnson, but merely to "comment" on them so far as to show that, in some respects, they were anticipated by Aëtius about the beginning of the sixth century.

Dr. Johnson's first proposition is, that "the phenomena of cholera result from the action of a morbid poison" (p. IO3); which differs little from "alienum enim valet venenum insidens, et ventrem ac intestina rodit, et humores ex universo corpore attrahit."

Dr. Johnson also says that "the action of repressive drugs, while the cause [of diarrhœa] continues in operation, is either nil or mischievous" 